\title{
All-conjugated block copolymers for efficient and stable organic solar cells with low temperature processing
}

Tyagi, Priyanka; Hua, Sun-Chen; Amorim, Daniel Roger; Faria, R. M.; Kettle, Jeffrey; Horie, Masaki

\section{Organic Electronics}

DOI:

10.1016/j.orgel.2018.01.032

Published: 01/04/2018

Peer reviewed version

Cyswllt i'r cyhoeddiad / Link to publication

Dyfyniad o'r fersiwn a gyhoeddwyd / Citation for published version (APA):

Tyagi, P., Hua, S-C., Amorim, D. R., Faria, R. M., Kettle, J., \& Horie, M. (2018). All-conjugated block copolymers for efficient and stable organic solar cells with low temperature processing. Organic Electronics, 55, 146-156. https://doi.org/10.1016/j.orgel.2018.01.032

\footnotetext{
Hawliau Cyffredinol / General rights

Copyright and moral rights for the publications made accessible in the public portal are retained by the authors and/or other copyright owners and it is a condition of accessing publications that users recognise and abide by the legal requirements associated with these rights.

- Users may download and print one copy of any publication from the public portal for the purpose of private study or research.

- You may not further distribute the material or use it for any profit-making activity or commercial gain

- You may freely distribute the URL identifying the publication in the public portal ?
}

Take down policy

If you believe that this document breaches copyright please contact us providing details, and we will remove access to the work immediately and investigate your claim. 
1 All-conjugated block copolymers for efficient and stable organic solar cells

Priyanka Tyagi ${ }^{\mathrm{a}}$, Sun-Chen Hua ${ }^{\mathrm{b}}$, Daniel Roger Amorim ${ }^{\mathrm{a}, \mathrm{c}}$, R.M. Faria ${ }^{\mathrm{c}}$, Jeff Kettle ${ }^{\mathrm{a}^{*}}$ and Masaki Horie ${ }^{\mathrm{b} *}$

${ }^{a}$ School of Electronic Engineering, University of Bangor, Dean St, Gwynedd, Bangor LL57 1UT, UK.

${ }^{b}$ Department of Chemical Engineering, National Tsing Hua University, 101, Sec. 2, Kuang-Fu Road, Hsinchu, Hsinchu City 30013, Taiwan.

${ }^{c}$ Instituto de Física de São Carlos, Universidade de São Paulo, 13560-970 São Carlos, SP, Brazil.

Abstract: The low embodied energy within Organic Photovoltaics (OPVs) provides the technology with a characteristic that surpasses all other PV materials. In this work, allconjugated block copolymers comprising of P3HT and PTB7-Th have been synthesized which enable even lower temperature processibility, thus reducing the embodied energy further. The all-conjugated block copolymers comprise of P3HT and poly[4,8-bis(5-(2ethylhexyl)thiophen-2-yl)benzo[1,2- $b ; 4,5-b^{\prime}$ ]dithiophene-2,6-diyl-alt-(4-(2-ethylhexyl)-3fluorothieno[3,4- $b$ ] thiophene-)-2-carboxylate-2-6-diyl)] (PTB7-Th). To synthesis these, a narrow-distributed, monobrominated P3HT $\left(M_{n}=7000, M_{w} / M_{n}=1.31\right)$ is synthesized by Grignard metathesis polymerisation. This is further reacted with distannyl and dibromo monomers of PTB7-Th by Stille step-growth polycondensation to provide the block copolymers of P3HT- $b$-PTB7-Th. In these reactions, block ratios are adjusted to 1 to 2 and 1 to 10 based on the numbers of the repeating units of the monomers (i.e. 3-hexylthiophene unit : two monomers of PTB7-Th $=1: 2$ and 1:10). The block copolymer showed high hole mobility of $5.9 \times 10^{-5} \mathrm{~cm}^{2} / \mathrm{Vs}$. The highest power conversion efficiency of $3.6 \%$, which was achieved with the photoactive layer processed at $60^{\circ} \mathrm{C}$, which is substantially lower than the Formatted: Font color: Red, Do not check spelling or grammar, Strikethrough

Formatted: Font color: Red, Do not check spelling or annealing temperature needed for standard P3HT-based solar cells. Furthermore, the stabilised lifetime of encapsulated devices is enhanced compared to P3HT and PTB7-Th devices, with no drop in efficiency noted for 7 days after initial burn in process. 


\section{Introduction}

Organic photovoltaics (OPVs) are categorised as a third generation solar cell technology and remain of commercial interest due to their unique attributes such as lowtemperature solution processability, flexibility, light weight and low energy payback time. ${ }^{1-9}$ The development of new synthetic routes and types of conjugated polymers has been the key reason for the rise of OPV efficiency to $13 \%$ in the past few years. ${ }^{1-9}$ To achieve high efficiencies, the main focus of research has been on developing low band gap conjugated polymers. ${ }^{10-13}$ Although several new materials have been developed during past decade, poly (3-hexylthiophene) (P3HT) has remained the most studied conjugated polymer for photovoltaic applications and there are numerous papers studying the effects of chemical, photo and thermal processes on device performance. ${ }^{14,15}$

One of the reasons for continuing research on P3HT based solar cells is the relatively stable operation and low cost synthetic procedure when compared to many more complex co-polymer material systems. Furthermore, it is available in $>1 \mathrm{~kg}$ quantities and has been demonstrated several times in the roll-to-roll manufacturing. However, P3HT based solar cells do suffer from two disadvantages; firstly, the power conversion efficiency (PCE) is lower than state of the art polymers and secondly, P3HTbased OPVs are only realised by processing the photoactive layer at high temperatures (typically more than $120^{\circ} \mathrm{C}$ ). ${ }^{5}$ By reducing the annealing temperature, the cost could be further reduced in addition to a reduction in the embodied energy that is needed for processing that the active layer possesses suitable crystallinity, homogeneous internal phase composition, and an optimal phase separation. ${ }^{5}$ One of the important parameter for PV modules is the energy payback time (EPBT). EPBT is the time required for the module to generate the amount of energy invested in order to fabricate it. The values of EPBT for crystalline silicon solar cell is about $2.4-4.1$ years ${ }^{16-18}$ while for the OPVs, the current value stands at $0.2-4$ years ${ }^{19}$. It has also been predicted that EPBT can be reduced to even 1 day for OPVs by reducing the process energy. The proportion of process energy devoted to annealing of the active area in $\mathrm{P} 3 \mathrm{HT}: \mathrm{PC}_{71} \mathrm{BM}$ solar cell is $26 \%{ }^{19}$. By reducing the annealing temperature, the EPBT of modules based on OPVs can be significantly reduced.

Recently block copolymers have been developed as the promising photovoltaic materials enabling better nanoscale control of blend interfaces within thin films without 
additional annealing or processing with additives. ${ }^{20-23}$ All-conjugated block copolymers contain two or more chemically different monomer units and are synthesized using one or more condensation polymerisation steps. ${ }^{24}$ It is possible to copolymerise two donor units to enhance their properties or one donor with an acceptor unit to lower the bandgap. ${ }^{25,26}$ Block copolymers are used in OFETs and OLEDs, but most commonly reported as a donor or acceptor material in OPV active layers to improve the morphology and also the electronic properties of the active layer. ${ }^{27}$ Although the block copolymer represents a huge potential for OPVs, the reported PCEs are very low around 1-3\% ${ }^{28}$ because the research has been focused on limited material systems due to difficulties in the synthesis and purification methods. Synthesizing block copolymers of two different donors can pave a route to enhance the donor properties.

In this paper, the synthesis of block copolymers consisting of P3HT and Poly[4,8-bis(5(2-ethylhexyl)thiophen-2-yl)benzo[1,2-b;4,5- $b$ ']dithiophene-2,6-diyl-alt-(4-(2-ethylhexyl)-3fluorothieno[3,4-b]thiophene-)-2-carboxylate-2-6-diyl)] (PTB7-Th) units is reported. The results show that by including even a low relative concentration of PTB7-Th block into the P3HT polymer chain, it is possible create a P3HT-based polymer that can be annealed at low temperature $\left(60^{\circ} \mathrm{C}\right)$ by the inclusion of the processing additive 1,8 -diiodooctane (DIO). This opens the possibility of lowering the embodied energy needed in OPV manufacture. Here we present the synthesis and photovoltaic studies of all-conjugated block copolymers P3HT- $b$ PTB7-Th.

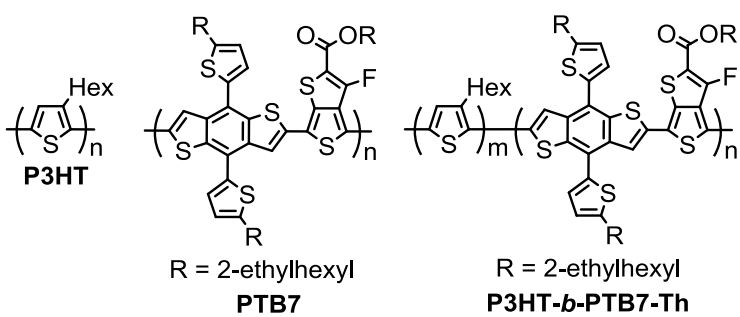

Fig.1 P3HT, PTB7-Th and their block copolymer. 


\section{Methods}

\subsection{Materials and general methods}

All the chemicals used for synthesis were purchased from Sigma-Aldrich and used without further purification. P3HT and PTB7-Th were synthesized according to the reported method. ${ }^{29}{ }^{1} \mathrm{H}$-NMR spectra were recorded at room temperature by using a Varian-Unity INVA-500 spectrometer. Matrix-assisted laser desorption ionisationtime-of-flight (MALDI-TOF) mass spectra were obtained by using a Bruker Autoflex III TOF/TOF equipped with a nitrogen laser $(337 \mathrm{~nm})$ in positive-ion mode. The molecular weights of the polymers were determined by gel permeation chromatography (GPC) using a JASCO 870 UV detector, a 880 pump, and American Polymer Standards Corporation ultrastyragel columns (Serial 2-15-89 A, B, and C) eluted with tetrahydrofuran (THF) as the solvent and polystyrene was used as the standard. UV-vis absorption spectra were measured at room temperature by using a JASCO V-630 UVVis spectrophotometer. Thermogravimetric analysis (TGA) was performed with a SDTQ600 thermogravimetric analyzer. Differential scanning calorimetry (DSC) was performed on a Perkin Elmer Diamond DSC. AFM images were obtained using a Park XE-70 AFM.

\subsection{Synthesis of P3HT- $b$-PTB7-Th}

Monomers

(4,8-bis(5-(2-ethylhexyl)thiophen-2-yl)benzo[1,2-b:4,5$b^{\prime}$ ]dithiophene-2,6-diyl)bis(trimethylstannane) (BDT-T) (41.9 mg, $\left.0.046 \mathrm{mmol}\right)$ and 2ethylhexyl-4,6-dibromo-3-fluorothieno[3,4-b]thiophene-2-carboxylate (TT-F) (19.6 $\mathrm{mg}, 0.042 \mathrm{mmol})$ and P3HT $(72.0 \mathrm{mg})$ were dissolved in a mixture of $2 \mathrm{~mL}$ of toluene and $0.2 \mathrm{~mL}$ of DMF. $\mathrm{Pd}\left(\mathrm{PPh}_{3}\right)_{4}(1.7 \mathrm{mg}, 1.5 \mu \mathrm{mol})$ was first purged with nitrogen for 15 min and then added as the catalyst. The mixture was then purged with nitrogen for 5 min. The reaction mixture was stirred and heated to reflux for $4 \mathrm{~h}$. It was then cooled to room temperature and poured into methanol. The precipitate was dried under vacuum. P3HT- $b$-PTB7-Th was obtained as dark blue solid (yield 87\%). This was then purified using a preparative GPC JAI LC-9204 with a column JAIGEL-3H-40 eluted with chloroform. 


\subsection{Device fabrication}

Hole-only and the photovoltaic devices were fabricated on prepatterned indium tin oxide (ITO) coated glass substrates $\left(R_{\mathrm{s}}=15 \Omega /\right.$ square, transparency $=84 \%$ purchased from Xinyan Ltd.). All the device processing has been undertaken in a cleanroom environment. For both sets of devices, the substrates were cleaned sequentially in deionised water, acetone and isopropanol each for $20 \mathrm{~min}$ in an ultrasonic cleaner and subsequently treated with an oxygen plasma for 5min. Hole- only devices were fabricated with a structure ITO/PEDOT:PSS/Polymer/Au (40 nm). Poly(3,4ethylenedioxythiophene):poly(styrenesulfonate) (PEDOT:PSS) was spin coated at 5000 $\mathrm{rpm}$ for $60 \mathrm{~s}$ in ambient conditions and annealed at $140^{\circ} \mathrm{C}$ for $20 \mathrm{~min}$. Substrates were then transferred into the glove box and the polymer layer was deposited in inert environment. The polymer layers were annealed at two different temperatures $100^{\circ} \mathrm{C}$ and $140^{\circ} \mathrm{C}$ to study the effect of annealing on hole mobility. Afterwards the top gold contacts were evaporated under high vacuum at deposition rate of $6 \mathrm{~nm} / \mathrm{min}$.

OPV devices were fabricated in an inverted structure ITO/ZnO (40 $\mathrm{nm}) /$ Photoactive layer/ $\mathrm{MoO}_{3}(13 \mathrm{~nm}) / \mathrm{Ag}(70 \mathrm{~nm})$. Zinc oxide was used as electron transport layer and was prepared by spin coating zinc acetate dehydrate (109 $\mathrm{mg}$ ) dissolved in 2-methoxyethanol $(1 \mathrm{~mL})$ and ethanolamine $(0.03 \mathrm{~mL})$ at $3500 \mathrm{rpm}$ for 30 $\mathrm{s}$ on ITO substrate. The substrates were then annealed at $150^{\circ} \mathrm{C}$ for $1 \mathrm{~h}$ for the zinc acetate to calcinate into $\mathrm{ZnO}$. Photoactive layer was composed of a 1:1 (weight ratio) blend of block copolymer and [6,6]-phenyl- $\mathrm{C}_{71}$-butyric acid methyl ester $\left(\mathrm{PC}_{71} \mathrm{BM}\right)$ as an acceptor. P3HT based solar cell were prepared with 1:1 (weight ratio) with $\mathrm{PC}_{71} \mathrm{BM}$ and PTB7-Th with 1:1.5. The blend solution was prepared in a $3 \mathrm{wt} \%$ concentration in chlorobenzene by stirring at $60^{\circ} \mathrm{C}$ for $24 \mathrm{~h}$. The effect of 1,8 -diiodooctane (DIO) was also studied by including a $2.5 \mathrm{wt} \%$ of DIO into the chlorobenzene solution. Same concentration of DIO was mixed for PTB7-Th based solar cell in the blend. P3HT based solar cell was prepared without adding DIO in the active layer. The solution was then filtered using a $0.45 \mu \mathrm{m}$ PTFE filter and spin coated at $1500 \mathrm{rpm}$ for $60 \mathrm{~s}$ in inert atmosphere. Photoactive layers were annealed at $60^{\circ} \mathrm{C}, 100^{\circ} \mathrm{C}$ and $140^{\circ} \mathrm{C}$ for $30 \mathrm{~min}$. The P3HT solar cell was fabricated by annealing the blend layer at $120^{\circ} \mathrm{C}$ for $30 \mathrm{~min}$ while the PTB7-Th blend was not annealed. Afterwards the $\mathrm{MoO}_{3}$ and $\mathrm{Ag}$ layers were evaporated under high vacuum at deposition rates of $0.6 \mathrm{~nm} / \mathrm{min}$ and $6 \mathrm{~nm} / \mathrm{min}$, respectively. Devices were encapsulated inside the glove box using UV curable epoxy 
and glass coverslips. Current-Voltage $(J-V)$ characteristics of these PV devices were measured under white light illumination (AM1.5) using an Oriel Newport AM1.5G solar simulator at an output intensity of $100 \mathrm{~mW} / \mathrm{cm}^{2}$. Lifetime test of devices was performed following ISOS-L-2 light soaking standards at 1 sun of irradiance (calibrated by the silicon reference cell). Devices were kept under open-circuit condition in between the I-V measurements. No additional cooling was applied to the devices during the lifetime test. Morphological characterization was performed using a Veeco dimension 3100 atomic force microscope (AFM). X-ray diffraction (XRD) measurements were performed using a Philips X-PERT 3040/60 instrument at $40 \mathrm{kV}$ voltage and $30 \mathrm{~mA}$ current with $\mathrm{Cu} \mathrm{K} \alpha$ radiation.

\section{Results and discussion}

\subsection{Polymer synthesis}

Scheme 1 shows the synthesis of P3HT- $b$-PTB7-Th. Initially, regioregular P3HT with a $\mathrm{Br}$ terminal group ( $\mathrm{P} 3 \mathrm{HT}-\mathrm{Br})$ was synthesized by Grignard metathesis polymerisation using 2-bromo-3-hexyl-5-iodothiophene or 2,5-dibromo-3hexylthiophene monomer. The optimum condition (Scheme S1 and Table S1 in the Supporting Information) provided P3HT-Br with a number-average molecular weight $\left(M_{\mathrm{n}}\right)$ of 7000 and a polydispersity (PDI) of 1.30 . Regioregularity ${ }^{30}$ of this polymer was estimated to be $93 \%$ by ${ }^{1} \mathrm{H}$ NMR spectroscopy. This polymer was then used for Stille coupling polymerisation with distannyl monomer BDT-T and dibromo monomer TT-F in the presence of $\mathrm{Pd}\left(\mathrm{PPh}_{3}\right)_{4}$ as a catalyst to give block copolymers of P3HT- $b$-PTB7$\mathrm{Th}$. In the polymerisation, the ratios of $\mathrm{P} 3 \mathrm{HT}-\mathrm{Br}$ to monomers were adjusted to 1 to 2 or 1 to 10 . These block copolymers were then separated into several fractions based on the molecular weight using a preparative GPC eluted with chloroform. 

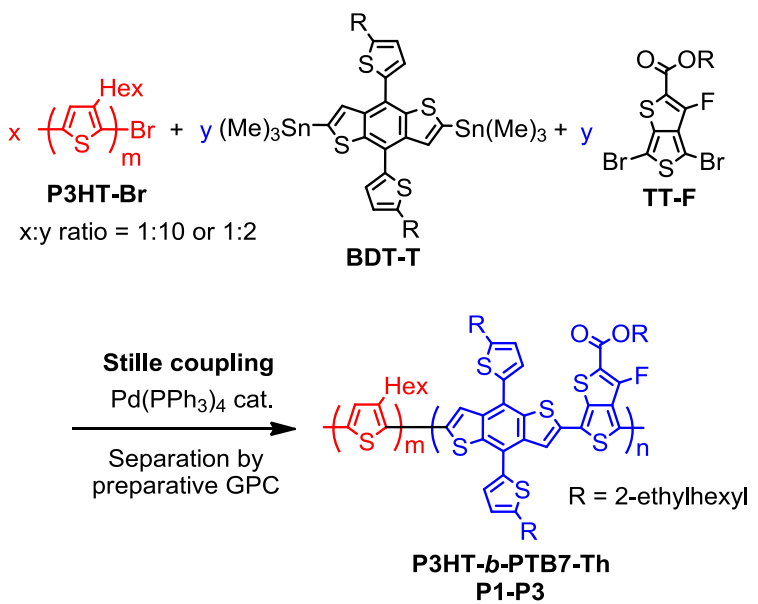

P1-P3

Scheme 1: Synthesis of P3HT- $b$-PTB7-Th.

Figs. $2 \mathrm{a}$ and $2 \mathrm{~b}$ show the elution curves for the reaction mixtures from the polymerisations using the ratios of $\mathrm{P} 3 \mathrm{HT}-\mathrm{Br}$ to monomers $1: 2$ and 1:10, respectively, recorded on the preparative GPC. These fractions are named P1-P3 in the order of elutions. The reaction with the larger amount of BDT-T and TT-F provided higher molecular weight block copolymers. Molecular weight of these fractionated polymers was then estimated using an analytical GPC (Fig. 2c) and these results are summarised in Table 1. All block copolymers have higher molecular weight $\left(M_{\mathrm{n}}=18 \mathrm{k}\right.$ for $\mathbf{P 1}, M_{\mathrm{n}}=$ $20 \mathrm{k}$ for P2 and $M_{\mathrm{n}}=56 \mathrm{k}$ for P3), than the original P3HT-Br $\left(M_{\mathrm{n}}=7 \mathrm{k}\right)$. 

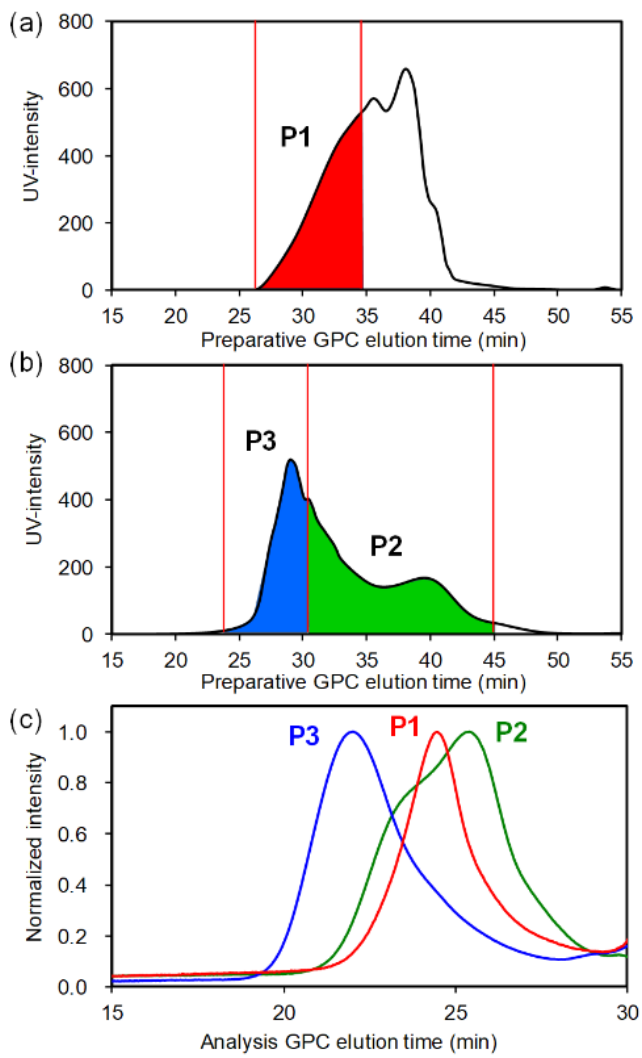

Fig. 2: Preparative GPC elution curve of P3HT- $b$ - PTB7-Th at $14 \mathrm{~mL} \mathrm{~min}^{-1}$ using $\mathrm{CHCl}_{3}$ as eluent. (a) P3HT to monomer ratio 1 to 2 and (b) P3HT to monomer ratio 1 to 10. (c) Analytical GPC curves of fractions of P3HT-b-PTB7-Th at $1 \mathrm{~mL} \mathrm{~min}^{-1}$ using THF as eluent. 
Table 1 Molecular weight and block ratio of polymers.

3

\begin{tabular}{|c|c|c|c|c|c|c|}
\hline Polymer & $M_{\mathrm{n}}$ & $M_{\mathrm{w}} / M_{\mathrm{n}}$ & $\lambda_{\max }(\mathrm{nm})$ & $\begin{array}{c}\text { P3HT } \\
\mathrm{wt}^{\%}\end{array}$ & $\begin{array}{c}\text { PTB7-Th } \\
\mathrm{wt} \%\end{array}$ & $\mathrm{m:n}^{a}$ \\
\hline P3HT-Br & 7000 & 1.31 & 450 & 100 & 0 & $42: 0$ \\
\hline PTB7-Th & 15800 & 3.30 & 691 & 0 & 100 & $0: 18$ \\
\hline P1 $^{b}$ & 18400 & 1.59 & 450 & ca. 93 & ca. 7 & ca. $111: 1.4$ \\
\hline P2 $^{c}$ & 19500 & 1.85 & 452 & ca. 42 & ca. 58 & ca. $93: 5$ \\
\hline P3 $^{c}$ & 55500 & 2.00 & 698 & ca. 26 & ca. 74 & ca. $217: 22$ \\
\hline
\end{tabular}

${ }^{a} \mathrm{~m}: \mathrm{n}$ ratio was determined by analytical GPC and UV-vis absorbance in chloroform solution. ${ }^{b} \mathbf{P} 1$ was obtained from a preparative GPC after Stille coupling using a feed ratio of x:y = 1:2 (Fig. 2a). ${ }^{c} \mathbf{P} 2$ and P3 were obtained from a preparative GPC after Stille coupling using a feed ratio of x:y = 1:10 (Fig. $2 b)$.

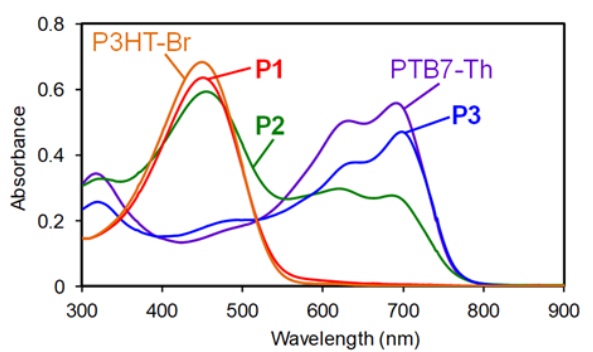

Fig. $3 \mathrm{UV}$-vis absorption spectra of polymers in $\mathrm{CHCl}_{3}$ solution.

UV-vis absorption spectra of the polymers were measured in chloroform solution (Fig. 3 and Table 1). The wavelength of maximum absorption $\left(\lambda_{\max }\right)$ of P3HT-Br and PTB7-Th occurs at $450 \mathrm{~nm}$ and $691 \mathrm{~nm}$, respectively. The higher $\lambda_{\max }$ of PTB7-Th than $\mathrm{P} 3 \mathrm{HT}-\mathrm{Br}$ is due to the presence of alternating donor-acceptor repeating units in PTB7Th, leading to a low bandgap property. Considering the spectrum shown in Fig. 3, P3 shows very similar absorption spectrum with PTB7-Th with absorption peaks at $630 \mathrm{~nm}$ and $698 \mathrm{~nm}$. From the absorbance at $630 \mathrm{~nm}(\mathrm{Abs}=0.373)$, a weight percent of P3HT to PTB7-Th was estimated as approximately to 26 to 74 . This ratio corresponds to a repeating units $\mathrm{m}: \mathrm{n}=217: 22$ found in combination with GPC analysis. Similarly, a weight percent of P3HT to PTB7-Th for P2 was estimated to 42 to 58, which 
corresponds to $\mathrm{m}: \mathrm{n}=$ 93:5. P1 shows a similar spectrum with P3HT-Br with a weight percent of P3HT to PTB7-Th of 93 to 7, leading to $\mathrm{m}: \mathrm{n}=111: 1.4$.

P1 shows a similar spectrum as P3HT-Br with a weight percent of P3HT to PTB7Th of 93 to 7, leading to $\mathrm{m}: \mathrm{n}=\underline{\mathrm{ca}}$. 111:1.4. The difference between $M_{\mathrm{n}}$ values of block copolymers and their P3HT wt\% determined from UV-vis spectroscopy is possibly due to the formation of ABA triblock copolymer of P3HT- $b$-PTB-7- $b-\mathrm{P} 3 \mathrm{HT}$.

To verify formation of the block copolymers, MALDI TOF mass spectrometry was utilised for the detailed structural analysis (Fig. 4). The spectrum of P3 contains repeating peaks with an interval of 166 , which corresponds to the mass of the repeating unit of 3-hexylthiophene $\left(\mathrm{C}_{10} \mathrm{H}_{14} \mathrm{~S}\right)$. The spectrum provides detailed information on the chemical structure of the polymer; peaks at $m / z=1056,1222$ and 1389 are attributed to the block copolymer $\mathrm{H}-(\mathrm{P} 3 \mathrm{HT})_{\mathrm{m}}-(\mathrm{PTB} 7-\mathrm{Th})_{1}-\mathrm{H}$ with an increase in the 3hexylthiophene unit. Similarly, peaks at $m / z=1134,1300$ and 1466 are attributed to $\mathrm{Br}$ terminated block copolymers with increase in the 3-hexylthiophene unit. In addition, peaks at $m / z=1945,1633$ and 1799 are attributed to the higher number of PTB7-Th unit. Thus the connection between P3HT and PTB7-Th blocks were verified. Thus the connection between P3HT and PTB7-Th blocks were verified. Other unidentified peaks might be attributed to oxidized thiophene rings. ${ }^{31}$

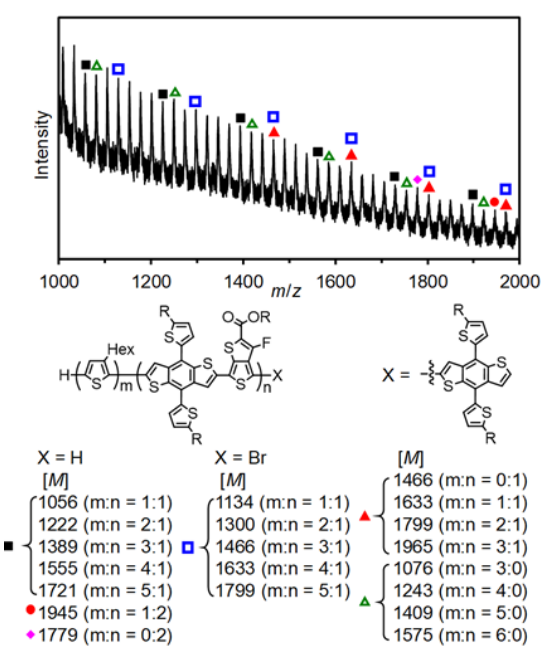




\subsection{Thermal properties and morphology}

TGA of the polymers was performed under nitrogen atmosphere and shown in Fig. 5a. The thermal properties of the polymers are summarized in the Table 2. 6 Decomposition temperature $\left(T_{d}\right)$ was estimated for $5 \%$ weight loss to be in a range between $350^{\circ} \mathrm{C}$ and $430^{\circ} \mathrm{C}$. The value of $T_{\mathrm{d}}$ was found to increase with the increased content of P3HT. This can be correlated to the higher thermal stability of P3HT. After heating up to $600{ }^{\circ} \mathrm{C}$, PTB7-Th and P3HT-Br contained residual weight of 52\% and $59 \%$, respectively. In block copolymers, polymers with larger amount of PTB7-Th block provided higher residual weight.

DSC was also performed under a nitrogen atmosphere at heating and cooling rates of $20{ }^{\circ} \mathrm{C}$ min $^{-1}$ and is shown in Fig. 5b and 5c. PTB7-Th shows insignificant melting or crystalline behavior, implying that PTB7-Th is amorphous. By contrast, P3HT-Br shows melting and crystallisation behavior at $240^{\circ} \mathrm{C}$ and $194^{\circ} \mathrm{C}$, respectively. Interestingly, the block copolymers P1-P3 show lower crystallisation temperature (181$185^{\circ} \mathrm{C}$ ) than P3HT-Br, even P1 containing only 7 wt $\%$ of PTB7-Th. This decrease in crystallisation temperature is possibly because crystallisation of P3HT needs to exclude the impurity, in a similar manner to PTB7-Th. The exclusion of the impurity affords slower crystallisation than pure P3HT, leading to the lower crystallisation temperature. 

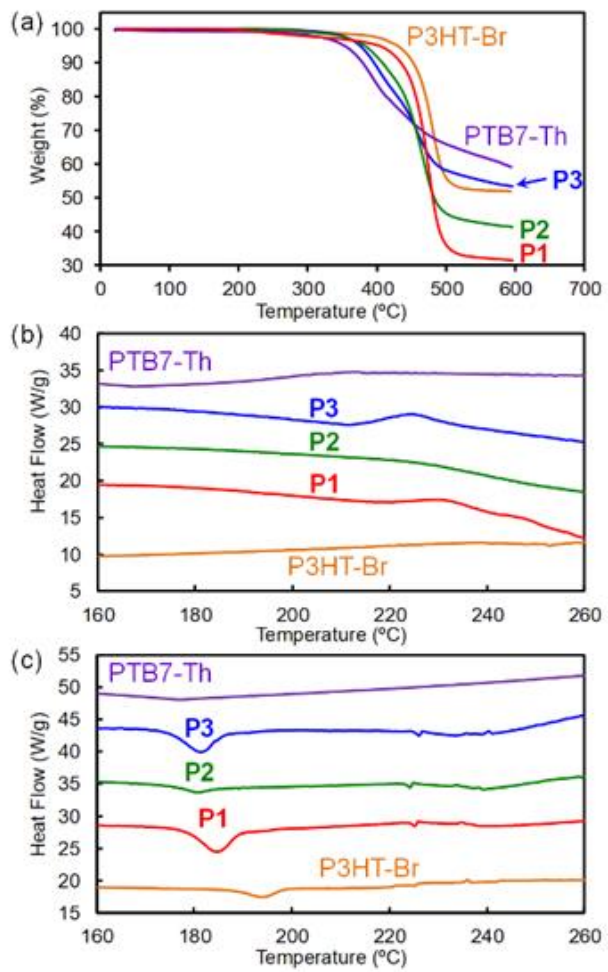

2 Fig. 5 Thermal properties of polymers. (a) TGA curves. DSC curves on (b) heating and (c) cooling.

5 Table 2 Thermal properties of polymers

\begin{tabular}{|c|c|rc|}
\hline Polymer & $T_{\mathrm{d}}\left({ }^{\circ} \mathrm{C}\right)^{a}$ & $T_{\mathrm{c}}\left({ }^{\circ} \mathrm{C}\right)^{b}$ & 6 \\
\hline PTB7-Th & 353 & 181 & 7 \\
\hline P3 & 376 & 181 & 8 \\
\hline P2 & 383 & 181 & 9 \\
\hline P1 & 404 & 185 & \\
\hline P3HT-Br & 430 & 194 & 10 \\
& & & 11 \\
\hline
\end{tabular}

${ }^{a} 5 \%$ weight loss temperature from TGA. ${ }^{b}$ Crystallisation temperature from DSC.

\subsection{Electrical studies}

To investigate the electrical properties of the block copolymers, hole-only devices were fabricated by the process described in the experimental section. We fabricated 
three devices for each polymer with active layer processed at room temperature, annealed at $100^{\circ} \mathrm{C}$ or at $140^{\circ} \mathrm{C}$. Fig. 6a shows the $\mathrm{J}-\mathrm{V}$ characteristics for the devices fabricated with P1. The current density has increased by annealing the polymer layer at $100^{\circ} \mathrm{C}$. However, after the annealing temperature is increased to $140^{\circ} \mathrm{C}$, the current density decreased drastically (as it did for P2 and P3). For the P3 device annealed at $100^{\circ} \mathrm{C}$, the current density follows the square power dependence of voltage in the high voltage region $(>3 \mathrm{~V})$. This indicates that the space charge limited conduction (SCLC) mechanism is dominant, in which the current density is given by Eq. 1 . (1)

the
the mobility, $V_{b i}$ the built-in voltage and $d$ the thickness of polymer. The value of builtin voltage was used to be $0.2 \mathrm{~V}$ (the difference in work function of ITO and Au) and the value of relative permittivity was 3 . The calculated hole mobility from the $J \alpha V^{2}$ region of the J-V characteristics was found to be $4.8 \times 10^{-6} \mathrm{~cm}^{2} / \mathrm{Vs}$ for the $\mathbf{P 1}$ at room temperature. The mobility increases to be $5.9 \times 10^{-5} \mathrm{~cm}^{2} / \mathrm{Vs}$ after annealing at $100^{\circ} \mathrm{C}$. For the P1 annealed at $140^{\circ} \mathrm{C}$, the device did not show SCLC. Overall the value of current density has also decreased when the annealing temperature has increased to $140^{\circ} \mathrm{C}$. This may be due to this temperature being very close to the thermal events such as glass transition or enthalpy relaxation. 

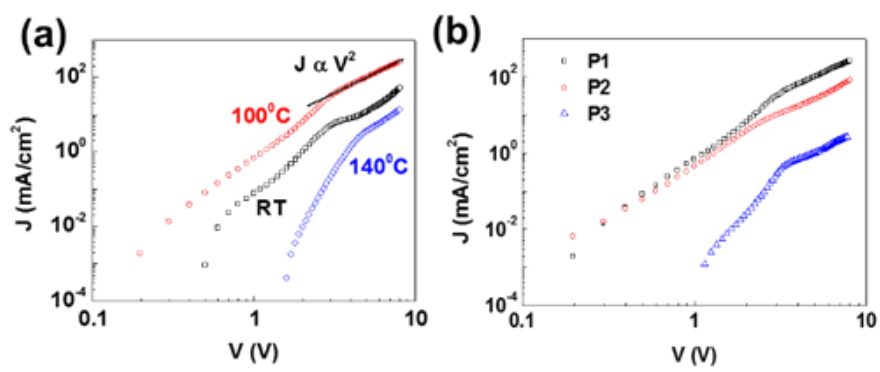

(c)

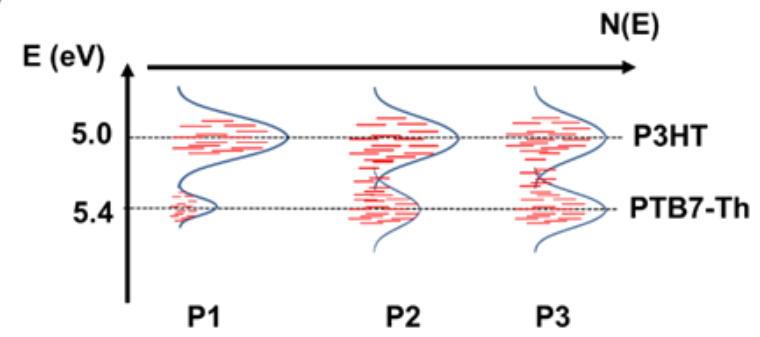

Fig. 6(a) J-V characteristics of the hole only devices with $\mathbf{P 1}$ processed at $100^{\circ} \mathrm{C}, 140^{\circ} \mathrm{C}$ and room temperature. The solid line is the reference for $J \alpha V^{2}$ region. (b) Comparison of the J-V characteristics of hole only devices of $\mathbf{P 1}, \mathbf{P 2}$ and $\mathbf{P 3}$ processed at $100^{\circ} \mathrm{C}$. (c) Schematic presentation of energetic distribution of the HOMO of copolymers P1, P2 and $\mathbf{P 3}$ on the basis of relative content of P3HT and PTB7-Th.

In a similar manner, the hole only devices were fabricated using $\mathbf{P 2}$ and $\mathbf{P 3}$ and the $\mathrm{J}-\mathrm{V}$ characteristics are shown in Fig. $6 \mathrm{~b}$ for the polymer layer annealed at $100^{\circ} \mathrm{C}$. As with P1, the optimal annealing temperature was found to be $100^{\circ} \mathrm{C}$ and the results are summarised in Table 3. The performance of both polymers was found to be substantially lower than P1. All the polymers showed trap free space charge limited conduction which differs from the reported conduction mechanism for P3HT, which is heavily limited by traps. ${ }^{32}$ Indeed, the reported hole trap density for P3HT is $3.5 \times 10^{16} \mathrm{~cm}^{-3}$ which is equivalent to the photogenerated carrier density in a typical photovoltaic device. ${ }^{31}$ This is one of the main limiting factors for efficiencies in P3HT:PCBM photovoltaic devices. As stated, the hole mobility for polymer $\mathbf{P 1}$ was found to be $5.9 \times 10^{-5} \mathrm{~cm}^{2} / \mathrm{Vs}$ which is comparable to the P3HT SCLC hole mobility $\left(3 \times 10^{-5} \mathrm{~cm}^{2} / \mathrm{Vs}\right){ }^{32}$ The higher mobility in $\mathbf{P 1}$ is likely to be a direct consequence of the reduced presence of traps. On the other 
hand polymers $\mathbf{P 2}$ and $\mathbf{P 3}$ showed lower mobility in comparison to the polymer $\mathbf{P 1}$. The reason behind this may be the increased content of PTB7-Th in the copolymers. This can be explained by Fig. 6c. The HOMO value of P3HT and PTB7-Th is $5.0 \mathrm{eV}$ and 5.4 $\mathrm{eV}$, respectively. In case of P1, the content of PTB7-Th is relatively low and the hole transport in $\mathbf{P 1}$ is dominated by the hopping of carriers in the HOMO of P3HT (5.0 eV). This makes the energetic disorder parameter of HOMO of P1 low. As the content of PTB7-Th increased in case of $\mathbf{P 2}$ and $\mathbf{P 3}$, the HOMO of copolymer is resulted from an overlap of the HOMO of P3HT and PTB7-Th as shown in the Fig. 6c. Therefore the energetic disorder has increased for higher content of PTB7-Th. The charge carrier mobility decreases as the energetic disorder increases $\left(\mu \alpha \exp \left(-\sigma^{2} / \mathrm{kT}\right)\right.$, where $\sigma$ is the energetic disorder, $\mathrm{k}$ the Boltzmann's constant and $\mathrm{T}$ the temperature). ${ }^{33}$ The increase in the energetic disorder is the reason behind the lower hole mobility of $\mathbf{P 2}$ and $\mathbf{P 3}$. The hole mobility of $\mathbf{P 1}$ is comparable to that of P3HT. Therefore the block copolymer molecules have good electronic properties required for their use as the donor material in photovoltaic devices.

Table 3 Hole mobility $\left(\mathrm{cm}^{2} / \mathrm{Vs}\right)$ calculated from the hole only devices for all three polymers fabricated from the films processed at room temperature and annealed at $100^{\circ} \mathrm{C}$.

\begin{tabular}{|c|c|c|}
\hline Polymer & RT processed & Annealed at 10020 \\
\hline P1 & $4.8( \pm 0.5) \times 10^{-6}$ & $5.9( \pm 0.7) \times 10^{-5} 21$ \\
\hline P2 & $3( \pm 0.6) \times 10^{-6}$ & $4.8( \pm 0.6) \times 10^{-5}$ \\
\hline P3 & $4.0( \pm 1) \times 10^{-7}$ & $1( \pm 0.8) \times 10^{-622}$ \\
\hline
\end{tabular}

\subsection{Photovoltaic studies}

OPV devices were fabricated with polymers P1-P3 and $\mathrm{PC}_{71} \mathrm{BM}$ as an acceptor. Fig. 7a shows the J-V characteristics of the polymer P1 with the active layer annealed at $60^{\circ} \mathrm{C}, 100^{\circ} \mathrm{C}$ and $140^{\circ} \mathrm{C}$. The PCE was found to be $1.49 \%$ for polymer annealed at $60^{\circ} \mathrm{C}$. As the annealing temperature increased to $100^{\circ} \mathrm{C}$, the efficiency also increased to $2.62 \%$. A further increase in annealing temperature resulted in a very small increase in the efficiency to $2.67 \%$. A similar pattern of efficiency was found in case of $\mathbf{P 2}$ and $\mathbf{P 3}$. The performance of $\mathbf{P 2}$ and $\mathbf{P 3}$ were lower than P1 due to lower hole mobility as a consequence of higher PTB7-Th content. Fig. 7b shows the J-V characteristics of the 
devices with P1, P2 and $\mathbf{P 3}$ for annealing temperature of $100^{\circ} \mathrm{C}$ and the photovoltaic performance parameters are summarized in Table 4.
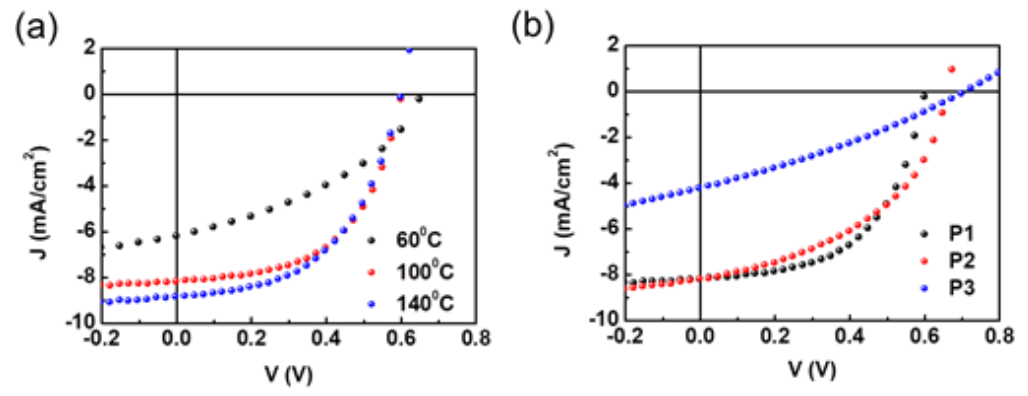

Fig. 7(a) J-V characteristics of the organic photo-voltaic devices with P1 processed at $60^{\circ} \mathrm{C}, 100^{\circ} \mathrm{C}$ and $140^{\circ} \mathrm{C}$ and room temperature. (b) Comparison of the $\mathrm{J}-\mathrm{V}$ characteristics of organic photo-voltaic devices of $\mathbf{P 1}, \mathbf{P 2}$ and $\mathbf{P 3}$ processed at $100^{\circ} \mathrm{C}$.

Similar to the hole only devices, the photovoltaic performance is also highest at $100^{\circ} \mathrm{C}$ annealing temperature. The reported value of optimum annealing temperature of $\mathrm{P} 3 \mathrm{HT}$ is in the range of $120^{\circ} \mathrm{C}$ to $140^{\circ} \mathrm{C}$. The processing temperature for the copolymers is significantly lower to this value. Additionally the solar cells maintained their PCE when the annealing temperature was increased to $140^{\circ} \mathrm{C}$. Although these copolymer solar cells showed high efficiency at annealing temperature of $100^{\circ} \mathrm{C}$, processing temperatures of less than $70^{\circ} \mathrm{C}$ required for fabrication on flexible substrates. The role of polymer layer annealing is to improve its morphology which is crucial for the photovoltaic performance. Morphology can also be improved by processing the polymer layer with additive. 
Table 4 Photovoltaic parameters of the OPVs based on P1, P2 and P3 fabricated at annealing temperature of $100^{\circ} \mathrm{C}$ and the parameters for the solar cells fabricated with 3 additive $\mathrm{DIO}$ at $60^{\circ} \mathrm{C}$.

\begin{tabular}{|l|l|l|l|l|}
\hline Polymer & $\mathrm{J}_{\mathrm{SC}}\left(\mathrm{mA} / \mathrm{cm}^{2}\right)$ & $\mathrm{V}_{\mathrm{OC}}(\mathrm{mV})$ & $\mathrm{FF}$ & PCE (\%) \\
\hline P1 & $8.1 \pm 0.1$ & $604 \pm 11$ & $53.6 \pm 1.86$ & $2.62 \pm 0.08$ \\
\hline DIO & $9.76 \pm 0.056$ & $580 \pm 15$ & $61.56 \pm 1.7$ & $3.51 \pm 0.16$ \\
\hline P2 & $8.4 \pm 0.41$ & $627 \pm 27$ & $45.2 \pm 2.48$ & $2.38 \pm 0.1$ \\
\hline DIO & $9.08 \pm 0.62$ & $580 \pm 2$ & $51.9 \pm 0.94$ & $2.77 \pm 0.2$ \\
\hline P3 & $3.28 \pm 0.79$ & $690 \pm 4$ & $30.0 \pm 0.6$ & $0.68 \pm 0.17$ \\
\hline DIO & $2.86 \pm 1.11$ & $660 \pm 30$ & $20.24 \pm 1.68$ & $0.45 \pm 0.5$ \\
\hline
\end{tabular}

Therefore, OPV devices were fabricated using the processing additive, DIO, which is known to improve the active layer morphology of PTB7-Th and leads to improved PCE. Fig. 8a shows the J-V characteristics of the device with P1 fabricated at the annealing temperature of $60^{\circ} \mathrm{C}$ without and with DIO. A remarkable increase in PCE was observed in this device from $1.49 \%$ to $3.51 \%$ by adding DIO. The champion cell efficiency was found to be $3.6 \%$. The increase in the efficiency is primarily due to increased short-circuit current density. This is likely to be due to the improved charge carrier generation which is often reported with the inclusion in DIO. ${ }^{34}$ Devices with the active layer annealed at $100^{\circ} \mathrm{C}$ and $140^{\circ} \mathrm{C}$ showed a reduction in average efficiency to $2.45 \%$ and $3.01 \%$, respectively. For P3, the PCE was increased to $2.38 \%$ although it required annealing at $140^{\circ} \mathrm{C}$, which represents a significant increase from the device without DIO $(0.68 \%)$. P2 showed the best PCE of $2.9 \%$ when annealed at $100^{\circ} \mathrm{C}$. Fig. $8 \mathrm{~b}$ shows the comparison of the devices for all three polymers. The photovoltaic parameters are shown in Table S2. Series and shunt resistances were also obtained by fitting the photovoltaic characteristics and summarized in Table S3. 
(a)

(c)
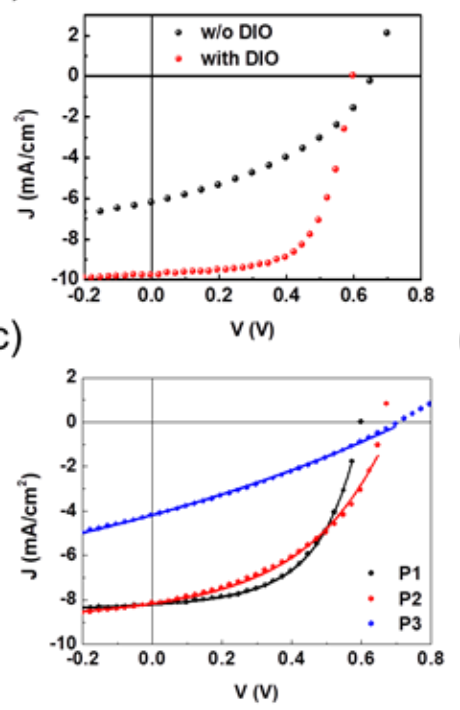

(b)
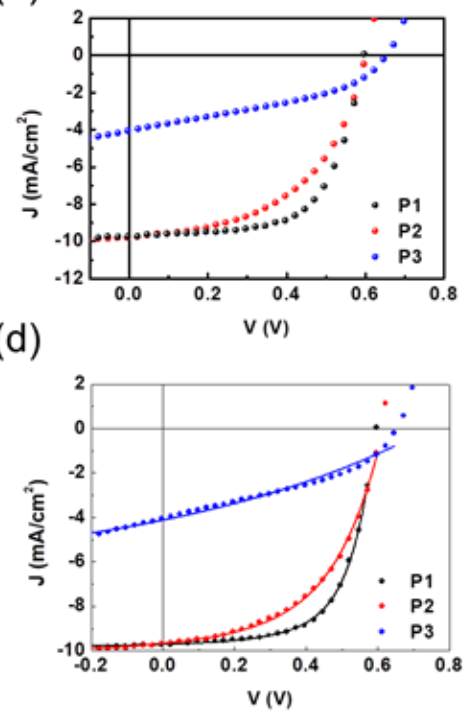

Fig. 8 (a) J-V characteristics of the OPV devices with $\mathbf{P 1}$ processed at $60^{\circ} \mathrm{C}$ without and with DIO. (b) Comparison of the J-V characteristics of organic photo-voltaic devices of P1, P2 and P3 with DIO processed at $60^{\circ} \mathrm{C}$. (c) Fitting of the photo-voltaic characteristics of OPVs processed at $100^{\circ} \mathrm{C}$ without DIO and (d) at $60^{\circ} \mathrm{C}$ with DIO using Eq. 2.

Overall the best efficiency was achieved with P1 mixed with DIO, but it is significant to note it was annealed at $60^{\circ} \mathrm{C}$. The annealing temperature is lower than the normal annealing temperature $\left(120^{\circ} \mathrm{C}\right.$ to $\left.140^{\circ} \mathrm{C}\right)$ used for P3HT based OPV devices. P1 contained the smallest proportion of PTB7-Th monomer fraction in the polymer chain (the ratio was 93:7). Therefore, the inclusion a small fraction of PTB7-Th block in the $\mathrm{P} 3 \mathrm{HT}$ polymer is able to reduce the processing temperature, which should lead to lower production costs and lower embodied energy within the PV costs.

Photovoltaic parameters were found to be strongly dependent on the processing conditions in these copolymer solar cells. Therefore a detailed analysis was performed. The generated photocarriers in photovoltaics depend on the recombination and extraction of carriers as derived by Koster et $\mathrm{al}^{35}$. We used the photocarrier density from their model to calculate the current density given in Eq. 2 


$$
J_{P H}=\frac{2 e(\mu F)^{2}\left[\sqrt{1+\frac{G L^{2}}{(\mu F)^{2}} \gamma}-1\right]}{L \gamma}
$$

where $\mu$ is the combined charge carrier mobility of electron and hole, $\gamma$ the bimolecular recombination coefficient, $G$ the photogeneration rate, $L$ the thickness of the active layer, and $\mathrm{F}=\left(V-V_{b i}\right) / L\left(V_{b i}\right.$ is the built-in voltage). Photovoltaic characteristics were fitted using Eq. 2 and the fittings are shown in Fig. 8(c) and (d), where a close fit is observed and the parameters summarized in Table 5. Langevin type recombination coefficient was considered for the fitting. A significant increase in the charge carrier mobility was observed by the DIO additive in case of P1 solar cells with the highest value of $1.1 \times 10^{-3} \mathrm{~cm}^{2} / \mathrm{Vs}$ at $60^{\circ} \mathrm{C}$. This corresponds to the conditions of the best performing solar cell. The obtained values of generation rate was found to be in the range of $3-6 \times 10^{21} \mathrm{~cm}^{-3}$ which can be associated to slight variations of the exciton dissociation $^{35}$. Therefore, the addition of DIO appears to improve the charge carrier mobility in the solar cell and has no significant effect on the charge carrier generation.

Table 5 Charge carrier mobility $\left(\mathrm{cm}^{2} / \mathrm{Vs}\right)$ and the generation rate $\left(\times 10^{21} \mathrm{~cm}^{-3} \mathrm{~s}^{-1}\right)$ used for the fitting of photovoltaic characteristics of solar cells fabricated with polymer processed at $60^{\circ} \mathrm{C}$ and $100^{\circ} \mathrm{C}$ (without and with DIO).

\begin{tabular}{|l|l|l|l|l|l|l|}
\hline Pol & \multicolumn{2}{|c|}{ P1 } & \multicolumn{2}{c|}{ P2 } & \multicolumn{2}{c|}{ P3 } \\
\hline $\mathrm{T}$ & $\mathbf{6 0}^{\circ} \mathbf{C}$ & $\mathbf{1 0 0}^{\circ} \mathbf{C}$ & $\mathbf{6 0}^{\circ} \mathbf{C}$ & $\mathbf{1 0 0}^{\circ} \mathbf{C}$ & $\mathbf{6 0}^{\circ} \mathbf{C}$ & $\mathbf{1 0 0}^{\circ} \mathbf{C}$ \\
\hline$\mu$ & $9.82 \times 10^{-6}$ & $9.63 \times 10^{-5}$ & $4.6 \times 10^{-5}$ & $5.82 \times 10^{-5}$ & - & $7.15 \times 10^{-6}$ \\
\hline DIO & $1.14 \times 10^{-3}$ & $4.62 \times 10^{-4}$ & $7.75 \times 10^{-5}$ & $6.31 \times 10^{-5}$ & $1.7 \times 10^{-6}$ & - \\
\hline G & 4.73 & 5.32 & 4.00 & 4.24 & - & 3.24 \\
\hline DIO & 3.96 & 3.09 & 6.38 & 6.15 & 4.47 & - \\
\hline
\end{tabular}

To further elucidate the effect of copolymerisation on the photovoltaic performance, morphological characterisation was performed by AFM. It is well known that the PV performance is dependent on the phase separation of the components and the morphology of the film. Figs. 9a and 9b show the AFM images of the P1 blended with $\mathrm{PC}_{71} \mathrm{BM}$ without and with $\mathrm{DIO}$ annealed at $60^{\circ} \mathrm{C}$. Polymer blend layer showed clear phase separation with the processing of DIO. The domain size was found to be in 
the range of 20-50 nm. Therefore, the copolymer P1 undergoes phase separation when it is processed at $60^{\circ} \mathrm{C}$ with DIO in a manner one would expect to lead to good device performance. We have also compared the morphology P1 with P2 and P3 blended with $\mathrm{PC}_{71} \mathrm{BM}$ processed at the temperature of their optimum performance $\left(100\right.$ and $140^{\circ} \mathrm{C}$ for $\mathbf{P 2}$ and $\mathbf{P 3}$ respectively) with DIO as shown in Figs. 9c and 9d. Clear phase separation was also observed for the blend films of P2 and P3. However the domain size reduced in case of $\mathbf{P 3}$ in comparison to $\mathbf{P 2}$. This leads to an interesting observation that the phase separation decreases with increasing content of PTB7-Th block. The phase separation was found to be most consistent with a high performing active layer for the case of P1, which explains the higher hole mobility and PCE. The results show that by adding very small amount of PTB7-Th in P3HT, the morphology of its blend layer can be significantly improved which leads to improved photovoltaic performance. The AFM topography images are shown in Fig. S8. The average roughness was found to be $1.02 \mathrm{~nm}$ for $\mathbf{P 1}, 1.18 \mathrm{~nm}$ for $\mathbf{P 2}$ and $0.89 \mathrm{~nm}$ for $\mathbf{P 3}$. The roughness is low for all three copolymer films.

(a)

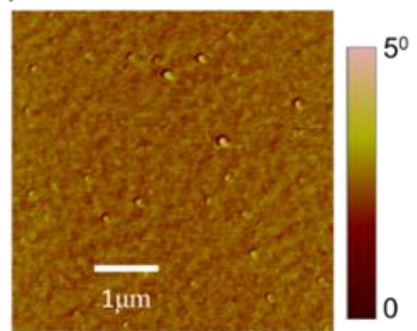

(c)

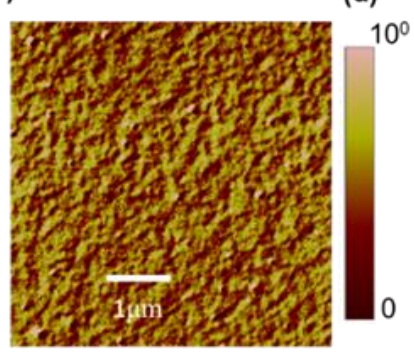

(b)

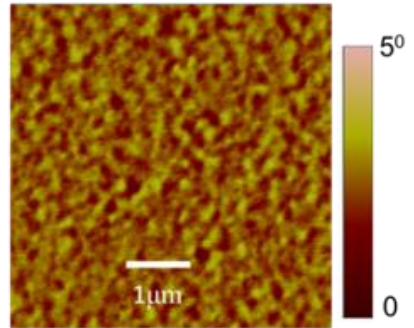

(d)

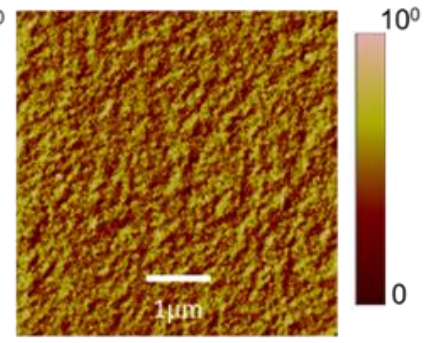

Fig. 9 AFM images of $\mathbf{P 1}$ processed at $60^{\circ} \mathrm{C}$ (a) without and (b) with DIO. AFM images of (c) $\mathbf{P 2}$ processed at $100^{\circ} \mathrm{C}$ and (d) $\mathbf{P 3}$ at $140^{\circ} \mathrm{C}$ with DIO. 
The reduced processing temperature is a very important factor in terms of the production cost and the energy payback time of the PV modules. P3HT:PC ${ }_{71} \mathrm{BM}$ based solar cell requires annealing at $120^{\circ} \mathrm{C}$ for optimum performance. Around $26.6 \%$ fraction of total process energy for fabrication is consumed in annealing of this layer. The energy required to anneal the P3HT:PC ${ }_{71} \mathrm{BM}$ layer is reported to be $368.85 \mathrm{MJ} / \mathrm{m}^{2}$ by Espinosa et al. ${ }^{19}$ Since the processing temperature for our solar cells is reduced to $60^{\circ} \mathrm{C}$, the required energy for annealing reduces significantly. This will reduce the total processing energy by $15.96 \%$. The energy payback time is calculated as the total energy required for the production of module divided by generated energy per year by the PV module. If a $1 \mathrm{~m}^{2}$ module has a $67 \%$ active area as found optimum by Espinosa et al ${ }^{19}$ and its utilisation in South Mediterranean situation (solar energy $=1700 \mathrm{KWh} / \mathrm{m}^{2} /$ year), the generated energy per year by the PV module will be $489.6 \mathrm{MJ} /$ year (considering module PCE of $3.5 \%$ obtained for our solar cells $)^{19,37}$. Reducing the annealing temperature by half can reduce the required process energy by $184.4 \mathrm{MJ} / \mathrm{m}^{2}$. Therefore reducing the processing temperature represents a huge advantage for the commercialisation of OPV modules.

(a)

(c)
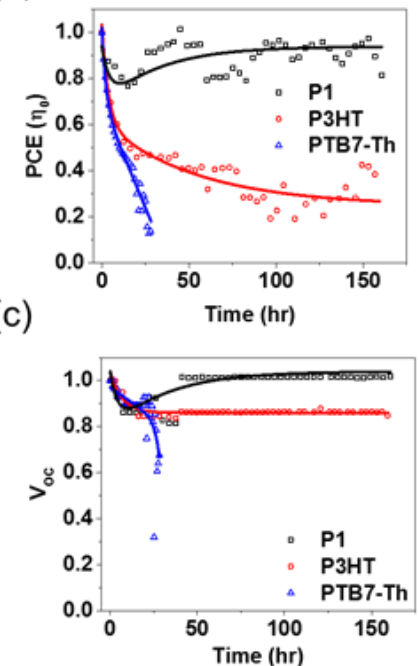

(b)

(d)
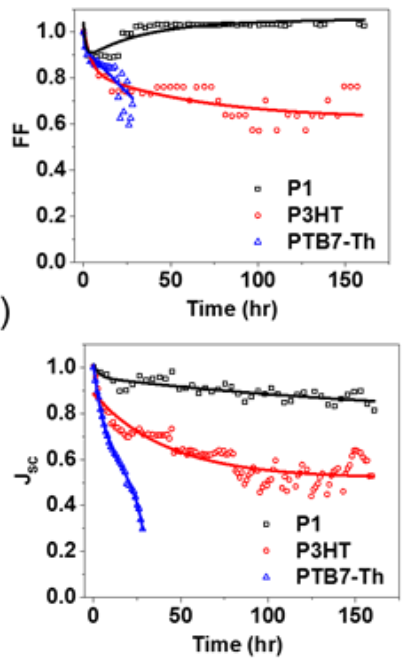

Fig. 10 Normalised PCE as a function of time for (a) P1, P3HT and PTB7-Th based solar cell for short time and. (b) FF, (c) $V_{\mathrm{OC}}$ and (c) $\mathrm{J}_{\mathrm{SC}}$ as a function of time for all three solar cells. The solid lines are for reference showing the trend of degradation. 
Stability studies were also performed with P1 solar cell and to compare it with the standard solar cells made with P3HT or PTB7-Th donor materials. P3HT:PCBM OPVs were fabricated and annealed at its optimum temperature $\left(120^{\circ} \mathrm{C}\right)$. The photovoltaic characteristics of P3HT and PTB7-Th based solar cells are shown in Fig. S9. The average PCE for P3HT based solar cell was $2.25 \%$ (champion cell at $2.4 \%$ ) and for PTB7-Th based solar cell was 7.28\%. We have also fabricated P3HT:PCBM OPVs at annealing temperature of $60^{\circ} \mathrm{C}$. The photovoltaic parameters of these OPVs (VOC $=$ $0.497 \mathrm{~V}, \mathrm{~J}_{\mathrm{SC}}=7.51 \mathrm{~mA} / \mathrm{cm}^{2}, \mathrm{FF}=0.33, \mathrm{PCE}=1.23 \%$ ) were significantly poor in comparison to copolymer OPVs and it was not possible to conduct a full lifetime test on them. Fig. 10a shows the PCE (normalised to initial PCE) as a function of time with continuous light exposure. All cells were non-encapsulated. The variation of FF is shown in Fig.10b. PTB7-Th based solar cell was found to be most unstable with the efficiency dropped down to $0.1 \%$ in 40 hours of continuous light soaking. Remarkably, the lifetime of P1 solar cell was also higher than the P3HT based solar cell. P1-PCBM OPVs also showed less burn-in in comparison to the P3HT-PCBM OPV. Further the lifetime trend for the P1 solar cell was vastly improved compared to the PTB7-Th based solar cell despite also being processed with DIO. It is worth noting that the PCE did not drop for more than 7 days (the time till the measurements performed) and fully recovered to original value for the P1-PCBM solar cell after the burnin occurred. PCE of $\mathrm{P} 1$ shows recovery after initial burnin process. This recovery is due to VOC and FF. This indicates that a reversible process of degradation is involved in these solar cells. Similar recovery of efficiency has been previously observed due to oxygen doping of the photoactive layer ${ }^{38}$ and ITO/PEDOT:PSS interface degradation ${ }^{39}$. However, in our case, this recovery was only observed in the copolymer solar cell. Therefore this should be originated due to the photoactive layer and may be due to some reversible trap formation inside the active layer. Other possible reason for the PCE recovery may be the evaporation of residual DIO during the burnin which has been found the major source of photoinduced degradation ${ }^{4}$. 
(a)

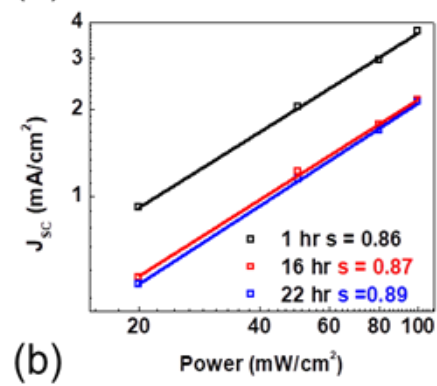

(b)

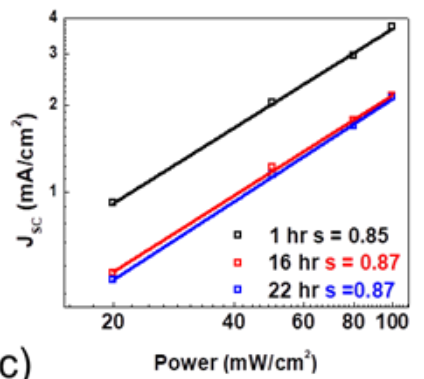

(c)

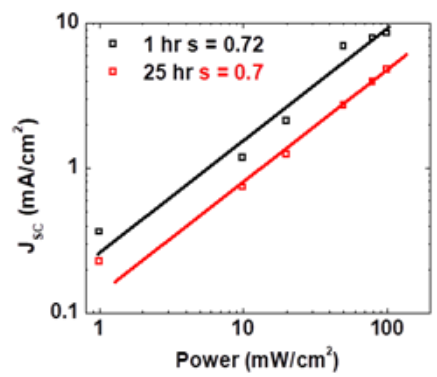

(d)

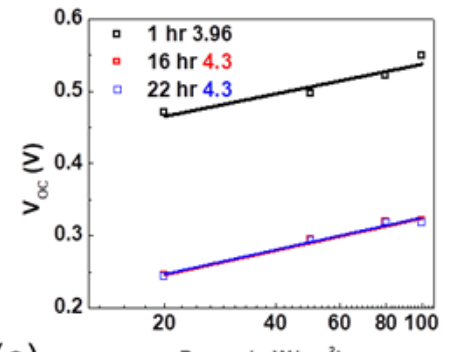

(e)

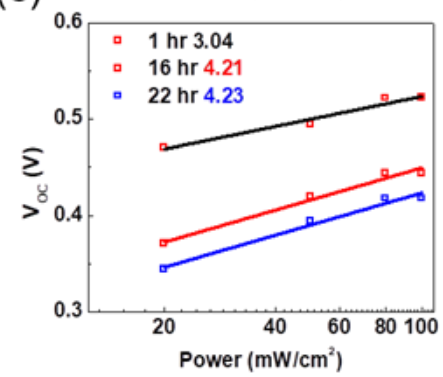

(f)

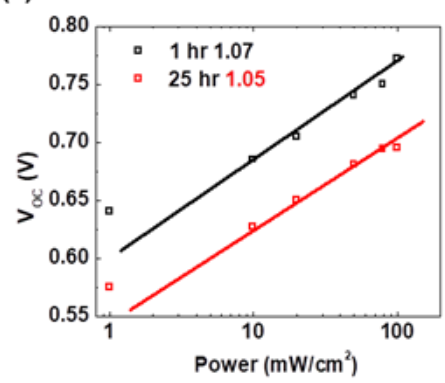

Fig. $11 \mathrm{JSC}_{\mathrm{SC}}$ as a function of incident power for (a) P1, (b) P3HT and (c) PTB7-Th at 3 different instant of time during degradation. $\mathrm{V}_{\mathrm{OC}}$ as a function of incident power for (d)

P1, (e) P3HT and (f) PTB7-Th at different instant of time during degradation.

Since the burn-in process is crucial for the high efficiency solar cell, it is essential to understand the mechanism of this process. Therefore the VOC and $\mathrm{J}_{\mathrm{SC}}$ were also measured as a function of time and shown in Fig. 10c and 10d. The burn-in loss in P1 solar cell was found to be due to decreases in $\mathrm{V}_{\text {OC }}$ similar to the PTB7-Th based solar cell while in P3HT based solar cell it is due to decrease in $\mathbf{J}_{\text {SC. Heumueller et al }}{ }^{40}$ have 
solar cell. $\mathrm{V}_{\mathrm{OC}}$ is determined by difference between the HOMO of donor and LUMO of acceptor, charge generation rate, electron-hole pair dissociation probability. ${ }^{41}$ The burnin loss in $\mathrm{V}_{\mathrm{OC}}$ can be explained due to the formation of light induced traps. ${ }^{41}$ The exact mechanism of burn-in loss requires in depth analysis of PV performance parameters. Therefore, the I-V characteristics were measured for different incident power during the degradation experiments. The $\mathrm{J}_{\mathrm{SC}}$ depends on the charge carrier generation and transport while $\mathrm{V}_{\mathrm{OC}}$ on the HOMO-LUMO difference and probability of charge carrier dissociation. Fig. 11a, 11b and 11c show the $\mathrm{J}_{\mathrm{SC}}$ as a function of power measured during degradation for P1, P3HT and PTB7-Th based solar cells, respectively. $\mathrm{J}_{\mathrm{SC}}$ has a power law dependence on the incident light intensity $\left(\mathrm{J}_{\mathrm{SC}} \alpha \mathrm{P}^{\mathrm{s}}\right.$, where $\mathrm{s}=0.75$ for space charge limited transport and $s=1$ for ohmic transport). The value of exponent did not vary significantly during the degradation process for both the P1 and P3HT based solar cell. Therefore, the loss in $\mathrm{J}_{\mathrm{SC}}$ is not due to degradation of charge transport in both solar cells. The main degradation source in both solar cell is due to charge carrier generation. The continuous decrease in the $\mathrm{J}_{\mathrm{SC}}$ with time supports this conclusion.

Fig. 11(d), (e) and (f) show the incident power dependence of $V_{O C}$ for P1, P3HT and PTB7-Th based solar cells, respectively. The slope of $V_{O C} v s \log P$ provides the information of recombination loss mechanism. If the slope is $\approx 1$, then Langevin recombination is the main loss mechanism and $\approx 2$ when traps are the dominating losses and the value of slope is more than 2 if additional loss mechanisms are involved. These additional mechanisms can be due energetic disorder, interface of polymer with the metal electrode etc. In P1 and P3HT OPVs, the slope > 2, indicating characteristics of the latter. Furthermore, the slope increases with increasing state of degradation suggesting that the recombination losses increased from the initial time of operation and this is more profound for the P3HT-based OPVs than the P1 based OPVs. Furthermore, it is significant to notice that the degradation of $\mathrm{P} 1$ based solar cell resemble closely with P3HT based solar cell and significantly different from PTB7-Th based solar cell. To summarise, the main degradation occurred due to the loss in $\mathrm{V}_{\mathrm{OC}}$. The main loss mechanism is due to trap assisted recombination; however, additional sources of loss are also involved which can be energetic disorder, degradation of polymer/metal interface ${ }^{38}$. 


\section{$\mathrm{X}$-ray diffraction results}

XRD measurements were performed on the copolymer blended with $\mathrm{PC}_{71} \mathrm{BM}$ and shown in Fig. 12.

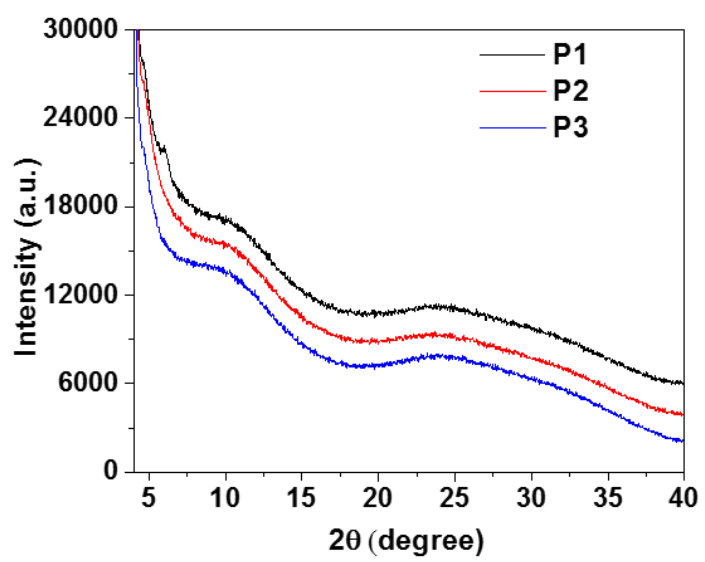

Fig. 12: XRD of copolymer blends with $\mathrm{PC}_{71} \mathrm{BM}$. The data has been offsetted for clarity.

Copolymers showed peaks at around $10^{\circ}$ and between $20^{\circ}-30^{\circ}$ corresponding to $\left(\begin{array}{lll}2 & 0 & 0\end{array}\right)$ and $\left(\begin{array}{lll}0 & 1 & 0\end{array}\right)$ diffraction. P1 showed addition peak at around $5.9^{0}$ corresponding to ( $\left.\begin{array}{lll}1 & 0 & 0\end{array}\right)$ diffraction showing better molecular packing in comparison to $\mathrm{P} 2$ and $\mathrm{P} 3$. The peak around $24^{\circ}$ originates due to $\pi-\pi$ stacking and the stacking distance was estimated from this peak, summarized in Table 6. This was found to be the highest in case of P1. Therefore the better performance of P1 can be correlated to the better molecular packing in comparison to $\mathrm{P} 2$ and $\mathrm{P} 3$.

Table 6: XRD peak positions and the d spacing calculated for P1 - P3.

\begin{tabular}{|l|ll|lr|lc|}
\hline & P 1 & & P 2 & & P 3 & \\
\hline $2 \theta$ (degree) & 23.7 & 10.1 & 24.22 & 10.32 & 24.22 & 9.82 \\
\hline d spacing $(\AA)$ & 3.75 & 8.75 & 3.67 & 8.57 & 3.67 & 9 \\
\hline
\end{tabular}




\section{Conclusions}

All-conjugated block copolymers comprising of P3HT and PTB7-Th have been synthesized to realise low temperature processed OPVs and show significantly lower processing temperature than conventional P3HT-based OPVs. The copolymer solar cell shows high performance in terms of both the PCE and lifetime. The processing temperature of copolymer solar cell is lower than the traditional high performance P3HT based solar cell. Low temperature processing can reduce the overall fabrication cost of the solar cell panels.

The polymers were obtained via Grignard metathesis polymerisation of 2,5dibromo-3-hexylthiophene, followed by Stille coupling polymerisation with the distannyl and dibromo monomers for the synthesis of PTB7-Th block. To fractionalise the reaction mixture, the preparative GPC was utilised. Characterisation using the analytical GPC and UV-vis spectrometry suggested that block copolymers with the high, middle and low P3HT/PTB7-Th compositions were obtained. MALDI-TOF mass spectrometry provided detailed chemical structural information of the block copolymers, showing covalent connection between P3HT and PTB7-Th blocks. The thermal and morphological properties of these polymers have been compared in terms of TGA and DSC. By increasing of the P3HT block, the crystallisation temperature and the amount of aggregations are increased, showing the properties of the block copolymers are significantly affected by both blocks.

The block copolymer with 93 wt\% P3HT composition showed the highest hole mobility of $6 \times 10^{-5} \mathrm{~cm}^{2} / \mathrm{Vs}$ and the best OPV performance of $3.6 \%$ with PC71BM acceptor. Together with high PCE, the copolymer solar cell also showed very high lifetime. Interestingly the optimum processing temperature was $60^{\circ} \mathrm{C}$, which is much lower than pure $\mathrm{P} 3 \mathrm{HT}\left(120^{\circ} \mathrm{C}\right)$. This will have a significant impact upon processing onto low temperature substrates, cost of manufacture and embodied energy within an OPV module. Further low temperature processing is also essential for the flexible and wearable energy devices. This is highly advantageous for their use in the future energy sources. Therefore the synthesized copolymers are ideal for future energy sources and can pave the way to efficient and stable solar energy sources. 


\section{Acknowledgements}

The authors would like to acknowledge the European Regional Development Fund (ERDF) and the Welsh European Funding Office (WEFO) for funding the 2nd Solar Photovoltaic Academic Research Consortium (SPARC II). This work was financially supported by Ministry of Science and Technology Taiwan and Frontier Research Center on Fundamental and Applied Sciences of Matters at National Tsing Hua University Taiwan.

\section{References}

1. S. Gunes, H. Neugebauer and N. S. Sariciftci, Chem. Rev., 2007, 107, 1324.

2. A. Rahmanudin and K. Sivula, CHIMIA International Journal for Chemistry, 2017, $71,369$.

3. Z. Ding, J. Kettle, M. Horie, S.-W. Chang, G. C. Smith, A. I. Shames and E. A. Katz, J. Mater. Chem. A, 2016, 4, 7274.

4. J. Kettle, H. Waters, M. Horie and G. C. Smith, Journal of Physics D: Applied Physics, 2016, 49, 085601.

5. W. L. Ma, C. Y. Yang, X. Gong, K. H. Lee and A. J. Heeger Adv. Funct. Mater., 2005, 15, 1617.

6. M. Horie, L. A. Majewski, M. J. Fearn, C. Y. Yu, Y. Luo, A. M. Song, B. R. Saunders and M. L. Turner, J. Mater. Chem., 2010, 20, 4347.

7. S. W. Chang, H. Waters, J. Kettle, Z. R. Kuo, C. H. Li, C. Y. Yu and M. Horie, Macromol. Rapid Commun., 2012, 33, 1927.

8. S. W. Chang, J. Kettle, H. Waters and M. Horie, RSC Adv. 2015, 5, 107276.

9. S. W. Chang, T. Muto, T. Kondo, M. J. Liao and M. Horie, Polym. J., 2017, 49, 113.

10. J. Liu, M. Durstock and L. Dai, Energy Environ. Sci., 2014, 7, 1297.

11. J. Zhao, Y. Li, G. Yang, K. Jiang, H. Lin, H. Ade, W. Ma and H. Yan, Nat. Energy, 2016, 1, 15027.

12. G. Li, W.-H. Chang and Y. Yang, Nat. Rev. Mater., 2017, 2, 17043.

13. K. Kawabata, M. Saito $\dagger$, I. Osaka and K. Takimiya, J. Am. Chem. Soc., 2016, 138, 7725.

14. K. Norrman, M. V. Madsen, S. A. Gevorgyan and F. C. Krebs, J. Am. Chem. Soc., $2010,132,16883$. 
15. X. Z. Wang, C. X. Zhao, G. Xu, Z. K. Chen and F. R. Zhu, Sol. Energy Mater. Sol. Cells, 2012, 104, 1.

16. V. M. Fthenakis and H. C. Kim, Sol. Energy, 2011, 85, 1609.

17. M. Raugei, P. Fullana-i-Palmer and V. Fthenakis, Energy Policy, 2012, 45, 576.

18. E. A. Alsema and M. J. de Wild-Scholten, Materials Research Society Symposium, Boston, MA, 2005.

19. N. Espinosa, M. Hosel, D. Angmo and F. C. Krebs, Energy Environ. Sci., 2012, 5, 5117.

20. M. He, F. Qiu and Z. Lin, J. Mater. Chem., 2011, 21, 17039.

21. S.-W. Chang and M. Horie, Chem. Commu., 2015, 51, 9113.

22. K. A. Smith, Y.-H. Lin, D. B. Dement, J. Strzalka, S. B. Darling, D. L. Pickel and R. Verduzco, Macromolecules, 2013, 46, 2636.

23. F. Nübling, H. Komber and M. Sommer, Macromolecules, 2017, 50, 1909.

24. M. Sommer, H. Komber, S. Huettner, R. Mulherin, P. Kohn, N. C. Greenham and W. T. S. Huck, Macromolecules, 2012, 45, 4142.

25. C. Guo, Y.-H. Lin, M. D. Witman, K. A. Smith, C. Wang, A. Hexemer, J. Strzalka, E. D. Gomez and R. Verduzco, Nano letters, 2013, 13, 2957.

26. Z. Li, X. Xu, W. Zhang, Z. Genene, W. Mammo, A. Yartsev, M. R. Andersson, R. A. Janssen and E. Wang, J. Mater. Chem. A, 2017, 5, 11693.

27. J. Chen, X. Yu, K. Hong, J. M. Messman, D. L. Pickel, K. Xiao, M. D. Dadmun, J. W. Mays, A. J. Rondinone, B. G. Sumpter and S. M. Kilbey Ii, J. Mater. Chem., 2012, 22, 13013.

28. J. W. Mok, Y.-H. Lin, K. G. Yager, A. D. Mohite, W. Nie, S. B. Darling, Y. Lee, E. Gomez, D. Gosztola, R. D. Schaller and R. Verduzco, Adv. Funct. Mater., 2015, $25,5578$.

29. L. Ye, S. Zhang, W. Zhao, H. Yao and J. Hou, Chem. Mater. 2014, 26, 3603.

30. K. Y. Kao, R. Y. Pei, H. L. Chen, J. H. Chen and S. A. Chen, RSC Adv., 2016, 6, 79209.

31. J. Mizukado, H. Sato, L. Chen, Y. Suzuki, S. Yamane, Y. Aoyama, Y. Yoshida, H. Suda, J. Mass Spectrom., 2015, 50, 1006-1012.

32. Z. Chiguvare and V. Dyakonov, Phys. Rev. B, 2004, 70, 235207.

33. H. Bassler, Phys. Stat. Sol. B, 1993, 175, 15.

34. D. H. Wang, P.-O. Morin, C.-L. Lee, A. K. K. Kyaw, M. Leclerc and A. J. Heeger, J. Mater. Chem. A, 2014, 2, 15052. 
35. L. J. A. Koster, M. Kemerink, M. M. Wienk, K. Maturová and R. A. J. Janssen, Adv. Mater. 2011, 23, 1670.

36. D. J. Coutinho and R. M. Faria, Appl. Phys. Lett., 2013, 103, 223304.

37. R. Garcia-Valverde, J. A. Cherni and A. Urbina, Prog. Photovolt: Res. Appl., 2010, 18, 535.

38. A. Seemann, T. Sauermann, C. Lungenscmied, O. Armbruster, S. Bauer, H.-J. Egelhaaf and J. Hauch, Solar Energy, 2011, 85, 1238-1249.

39. Y. Galagan, A. Mescheloff, S. C. Veenstra, R. Andriessen and E. A. Katz, Phys. Chem. Chem. Phys., 2015, 17, 3891-3897.

40. T. Heumueller, W.R. Mateker, I.T. Sachs-Quintana, K. Vandewal, J.A. Bartelt, T.M. Burke, T. Ameri, C. J. Brabec and M.D. McGehee, Energy Envorn. Sci., 2014, 7, 2974.

41. N. Grossiord, J. M. Kroon, R. Andriessen and P.W.M. Blom, Org. Elect., 2012, 13, 432. 